\title{
The testis temperature of anaesthetized quail
}

\author{
M. Jarman and T. E. Thompson \\ Department of Zoology, University of Bristol, Bristol BS8 1UG, U.K.
}

\begin{abstract}
Summary. The temperatures of the left testis, and of the adjacent viscera, of 11 anaesthetized quail were measured. The testes averaged $0.6^{\circ} \mathrm{C}$ cooler than the surrounding viscera and $1.3^{\circ} \mathrm{C}$ cooler than the flight muscle. We suggest that endothermic reactions are the cause of the testicular temperature being below that of its immediate surroundings.
\end{abstract}

\section{Introduction}

Testis temperatures in the mammalian scrotum have long been a source of interest to reproductive physiologists (see, for example, Moore \& Quick, 1924; Badenoch, 1945; Cowles, 1965; VanDemark $\&$ Free, 1970). In contrast, few observations have been published on the testicular temperature in birds (Herin, Booth \& Johnson, 1960). The interpretation of bird temperatures is, in any case, complicated by the effects of evaporative cooling in the air-sacs. Moreover, the absence of brown fat and of non-shivering thermogenesis (Janský, 1973; George, 1984) mean that heat production in the thermal core of a bird's body is rather localized. The concept of a core temperature, so useful when considering the animal as a whole, is of less value to the worker concerned with temperature differences within that 'core'.

With a view to testing the possibility that endothermic reactions within the testis might cool it, measurements were made of the temperatures of quail testes and these were compared with simultaneous estimates of the temperatures of the surrounding viscera (as measured between folds of intestine). For comparison, the temperature of a point in the pectoralis major flight muscle, a well-vascularized tissue, was likewise continuously monitored.

\section{Materials and Methods}

The male quail (Coturnix coturnix japonica) used were at least 7 weeks old and had been brought to sexual maturity under a lighting regimen of $20 \mathrm{~h}$ light to $4 \mathrm{~h}$ darkness for 3 weeks. Experiments were started between 2 and $8 \mathrm{~h}$ after the dark-to-light transition, and following a day's fasting (which avoided interference from digestive and absorptive events). The birds were anaesthetized with a breathing mixture of $80 \% \mathrm{~N}_{2} \mathrm{O}$ and $20 \% \mathrm{O}_{2}$ passed over halothane (veterinary grade $\mathrm{CF}_{3} \mathrm{CHClBr}$; May \& Baker Ltd, Dagenham, Kent, U.K.). The contents of the body cavity were exposed by a lateral incision close to the left testis. Copper-constantan thermocouples, mounted in 25-gauge hypodermic needles, were inserted in various parts of the bird, always including one in the left testis and one between the intestinal coils immediately adjacent. Viscera were then heaped over the testis, the edges of the incision into the abdominal cavity were pulled together and the flank was covered with cotton-wool. Temperatures were read at $0 \cdot 5$-min intervals.

The experiments were carried out in a small bench-top enclosure. The environment of the bird was laboratory air, heated to $29^{\circ} \mathrm{C}$ and circulated by a fan within the enclosure. All the thermocouple 'cold junctions' were inserted deep in holes in a block of brass whose temperature was controlled at $37 \cdot 1 \pm 0 \cdot 05^{\circ} \mathrm{C}$. Care was taken not to use the same thermocouple 'hot junction' in the testis in each 
experiment, but to permutate the available junctions, lest there were any unsuspected differences between the individual junctions.

It may be objected that the temperature recorded by the thermocouple junction is not exactly the same as that of the organ in which it is inserted because of heat conduction along the needle. The effect is probably small (Grinsted, Blendstrup, Andreasen \& Byskov, 1980). Heat conduction along the needle whose point is in the testis will, in any case, be from the surrounding viscera (warmer) to the testis (cooler), thus heating the latter and reducing the effect demonstrated in this paper. Likewise the needle with its point in the viscera conducts heat from the viscera to the (cooler) ambient atmosphere, thus cooling the viscera and again reducing the effect measured in this work.

Another possible objection regarding the thermocouple needles is that they might provoke a tissue reaction causing local heating. It is improbable that this is the source of the temperature differences recorded because the testis needle actually penetrated living tissue in the testis, while the viscera needle merely lay between folds of the intestine; the greater injury-heating would therefore be expected in the testis, again reducing the effect shown.

Measurements were carried out for 23-65 min with the birds alive and subsequently for a variable period after the subjects had been killed by cutting down their oxygen and increasing the halothane concentration in the inspired gas to a lethal level. Time of death was defined as the moment when breathing stopped permanently.

\section{Results}

After anaesthesia, the temperature of the bird as a whole (judged by the average temperature of all the needles inserted) normally took a few minutes to settle. It then changed steadily (usually diminishing), until the bird was killed (for discussion of changes in blood flow, tissue metabolic rate and body temperature during anaesthesia, see, for example, Goldberg \& Roe, 1966; Hunter, 1979). The rate of change of temperature was between $+0 \cdot 10$ and $-0 \cdot 18^{\circ} \mathrm{C} \mathrm{min}^{-1}$. The fastest falls occurred in birds with the lowest breathing rates under anaesthesia (Spearman's rank correlation coefficient, $\left.r_{\mathrm{s}}=0.63 ; P<0.025\right)$. These were judged to be those birds suffering the deepest anaesthesia (on the ground that the effects of halothane in man include predispositions to heat loss and to reduced ventilation).

By $5 \mathrm{~min}$ after the start of recording, the temperatures of testis, viscera and flight muscle had usually steadied (Table 1). The temperature recorded for the flight muscle was usually the highest of

Table 1. Temperatures $\left({ }^{\circ} \mathrm{C}\right)$ of flight muscle, testis and adjacent viscera in 11 anaesthetized quail, measured $5 \mathrm{~min}$ and $20 \mathrm{~min}$ after anaesthesia

\begin{tabular}{|c|c|c|c|c|c|c|c|}
\hline \multirow[b]{2}{*}{ Bird no. } & \multicolumn{2}{|c|}{ Flight muscle } & \multicolumn{2}{|c|}{ Left testis } & \multicolumn{2}{|c|}{ Viscera } & \multirow{2}{*}{$\begin{array}{l}\text { Average testis } \\
\text { minus viscera }\end{array}$} \\
\hline & $5 \mathrm{~min}$ & $20 \mathrm{~min}$ & $5 \mathrm{~min}$ & $20 \mathrm{~min}$ & $5 \mathrm{~min}$ & $20 \mathrm{~min}$ & \\
\hline 1 & $37 \cdot 1$ & $35 \cdot 3$ & $34 \cdot 7$ & $33 \cdot 7$ & $36 \cdot 0$ & $34 \cdot 0$ & -0.99 \\
\hline 2 & $39 \cdot 0$ & $37 \cdot 7$ & $37 \cdot 5$ & $37 \cdot 0$ & $38 \cdot 2$ & $37 \cdot 7$ & -0.90 \\
\hline 3 & $39 \cdot 0$ & $37 \cdot 7$ & $37 \cdot 2$ & $36 \cdot 3$ & 37.9 & 36.8 & -0.42 \\
\hline 4 & $38 \cdot 9$ & $39 \cdot 2$ & $37 \cdot 3$ & $38 \cdot 0$ & 38.6 & $38 \cdot 7$ & -0.67 \\
\hline 5 & $39 \cdot 5$ & $38 \cdot 2$ & $37 \cdot 6$ & $37 \cdot 1$ & $39 \cdot 4$ & $37 \cdot 7$ & -0.93 \\
\hline 6 & \multicolumn{2}{|c|}{ Not measured } & $37 \cdot 2$ & $35 \cdot 4$ & 37.8 & $36 \cdot 0$ & -0.57 \\
\hline 7 & \multicolumn{2}{|c|}{ Not measured } & $36 \cdot 4$ & $35 \cdot 9$ & 36.7 & $36 \cdot 3$ & -0.37 \\
\hline 8 & $39 \cdot 7$ & $39 \cdot 2$ & $38 \cdot 2$ & 37.9 & 38.9 & $38 \cdot 4$ & -0.60 \\
\hline 9 & $39 \cdot 7$ & $40 \cdot 1$ & $38 \cdot 5$ & $39 \cdot 7$ & 38.9 & $39 \cdot 6$ & +0.09 \\
\hline 10 & $40 \cdot 0$ & $41 \cdot 3$ & $38 \cdot 8$ & $40 \cdot 1$ & $39 \cdot 6$ & $41 \cdot 3$ & -0.91 \\
\hline 11 & $39 \cdot 2$ & $39 \cdot 2$ & $38 \cdot 1$ & 37.9 & $38 \cdot 5$ & $38 \cdot 3$ & -0.37 \\
\hline Mean & $39 \cdot 12$ & 38.66 & $37 \cdot 41$ & $37 \cdot 18$ & $38 \cdot 23$ & $37 \cdot 71$ & -0.60 \\
\hline s.d. & \pm 0.85 & \pm 1.71 & $\pm 1 \cdot 13$ & \pm 1.85 & \pm 1.09 & \pm 1.94 & \pm 0.33 \\
\hline s.e. & $\pm 0 \cdot 28$ & \pm 0.57 & $\pm 0 \cdot 34$ & \pm 0.55 & \pm 0.33 & \pm 0.59 & $\pm 0 \cdot 10$ \\
\hline
\end{tabular}


those measured at the 3 sites. The shortfall in temperature of the testis below that of the surrounding viscera, averaged over the standard 15 -min period, was significantly different from zero $(t=6 \cdot 0$; $P<0.001)$.

Table 2 compares testis-viscera temperature differences before and after death in all those birds for which continuous records of duration at least 4 min both before and after death are available. The numerical magnitude of the temperature difference was slightly, but significantly, higher after death than before $(t=2.73 ; P<0.05$ in paired $t$ test $)$. This result would be consistent with the view that blood flow in the living birds tends to equalize temperatures of testis and viscera. It would not be consistent with the view that in life a temperature gradient was set up by heat from adjacent metabolizing tissue passing to the cooler testis and escaping to a still cooler blood stream, and that such a gradient merely persisted post mortem by the thermal inertia effect.

Table 2. Testis-viscera temperature differences before and after death in 9 quail, showing that differences established in the live bird continue after death

\begin{tabular}{lccccc}
\hline & \multicolumn{2}{c}{ Before death } & & \multicolumn{2}{c}{ After death } \\
\cline { 2 - 3 } \cline { 5 - 6 } Bird no. & $\begin{array}{c}\text { Length of record } \\
(\mathrm{min})\end{array}$ & $\begin{array}{c}\text { Temp. diff. } \\
\left({ }^{\circ} \mathrm{C}\right)\end{array}$ & & $\begin{array}{c}\text { Length of record } \\
(\mathrm{min})\end{array}$ & $\begin{array}{c}\text { Temp. diff. } \\
\left({ }^{\circ} \mathrm{C}\right)\end{array}$ \\
\hline 2 & 53 & -0.89 & & 4 & -0.86 \\
3 & 12 & -0.77 & & 9 & -0.88 \\
6 & 14 & -0.63 & & 4 & -0.61 \\
7 & 26 & -0.39 & & 18 & -1.02 \\
9 & 32 & +0.32 & & 4 & +1.04 \\
11 & 23 & -0.37 & & 31 & -0.29 \\
12 & 5 & -0.92 & & 35 & -1.11 \\
13 & 5 & -0.92 & & 22 & -1.57 \\
14 & 5 & -1.26 & & 12 & -1.90 \\
Mean & & -0.65 & & -0.80 \\
\hline
\end{tabular}

\section{Discussion}

The temperature difference between testis and viscera was consistent throughout the duration of the observations. It (a) occurred notwithstanding the fact that halothane drastically reduces the breathing rate of the birds and (b) persisted, or even slightly increased, after the birds had been killed and were therefore not breathing and probably not circulating blood. It is therefore difficult to attribute the observed temperature differences either to cooling by evaporation in the air-sacs or to heat transfer via the blood stream.

In the past, Herin et al. (1960) have claimed that cooling of the testes via the adjacent air-sacs neither occurs nor is required in the domestic fowl; Cowles (1965), reviewing work on birds in general, has argued the contrary. That the present work fails to show cooling via the air-sacs is not surprising in view of the sluggishness of breathing which halothane causes.

By elimination, it is hard to escape the conclusion that endothermic reactions are the cause of the testicular temperature being below that of the surrounding tissue, as suggested for rabbit antral follicles by Grinsted et al. (1980). Whatever its cause, the reduction in testicular temperature, although small, may be of physiological significance for spermatogenesis, as discussed by Riley (1937) for a passerine bird and by Cowles (1965) for a wide range of organisms.

We thank Professor B. K. Follett and Dr T. J. Nicholls for help with the experiments. 


\section{References}

Badenoch, A.W. (1945) Descent of the testis in relation to temperature. Br. med. J. 2, 601-602.

Cowles, R.B. (1965) Hyperthermia, aspermia, mutation rates and evolution. Q. Rev. Biol. 40, 341-367.

George, J.C. (1984) Thermogenesis in birds. In Thermal Physiology, pp. 467-473. Ed. J. R. S. Hales. Raven, New York.

Goldberg, M.J. \& Roe, C.F. (1966) Temperature changes during anaesthesia and operation. Arch Surg. (Chicago) 93, 365-369.

Grinsted, J., Blendstrup, K., Andreasen, M.P. \& Byskov, A.G. (1980) Temperature measurements of rabbit antral follicles. J. Reprod. Fert. 60, 149-155.

Herin, R.A., Booth, N.A. \& Johnson, R.M. (1960) Thermoregulatory effects of abdominal air sacs on spermatogenesis in domestic fowl. Am. J. Physiol. 198, 1343-1345.
Hunter, A.R. (1979) Body temperature during general anaesthesia. In Body Temperature, pp. 587-594. Eds P. Lomax \& E. Schönbaum. Dekker, New York.

Janský, L. (1973) Non-shivering thermogenesis and its thermoregulatory significance. Biol. Rev. 48, 85-132.

Moore, C.R. \& Quick, W.J. (1924) The scrotum as a temperature regulator for the testis. Am. J. Physiol. 68, $70-79$.

Riley, G.M. (1937) Experimental results on spermatogenesis in the house sparrow, Passer domesticus. Anat. Rec. 67, 327-352.

VanDemark, N.L. \& Free, M.J. (1970) Temperature effects. In The Testis, vol. III, pp. 233-312. Eds A. D. Johnson, W. R. Gomes \& N. L. VanDemark. Academic Press, New York.

Received 26 March 1986 